\title{
Theories Explaining Stock Price Behavior: A Review of the
}

\section{Literature}

\author{
Fatima Ruhani \\ Ph.D Candidate \\ School of Business Innovation and Technopreneurship \\ University Malaysia Perlis \\ Kangar, Malaysia \\ Email: fruhani@gmail.com \\ Md. Aminul Islam $P h D$ \\ Associate Professor \\ School of Business Innovation and Technopreneurship \\ University Malaysia Perlis \\ Kangar, Malaysia \\ Email: amin@unimap.edu.my

\section{Tunku Salha Tunku Ahmad PhD \\ Senior Lecturer and Dean} \\ School of Business Innovation and Technopreneurship \\ University Malaysia Perlis \\ Kangar, Malaysia \\ Email: salha@ unimap.edu.my
}

\begin{abstract}
Estimation of stock price behavior is important for several reasons and for different stakeholders in the market. Many studies are trying to put forward theories to explain this phenomenon and more still have tried to use these theories in order to predict future changes in prices. The growing linkages of national markets in currency, commodity and stock with world markets and the existence of common players, have given stock price behavior a new property - that of its speedy transmissibility across markets. The present study aims to review the existing literature of the theories explaining stock price behavior. To review the literature, this study presented the theories in two different eras. First era is the pre modern era in financial theory and the second one is the theories in modern financial economics with technological development
\end{abstract}

Keywords: Stock Price Behavior, Volatility, Financial Theory. Modern Financial Economics 


\section{Introduction}

It is apparent that there are immensely wide day-to-day changes in the prices quoted on most stock exchanges. Many studies are trying to put forward theories to explain this phenomenon and more still have tried to use these theories in order to predict future changes in prices. In fact, there is no universally accepted body of work explaining what is behind these day-to-day price changes. Estimation of stock price behavior is important for several reasons and for different people in the market. Behavior of stock price is supposed to be dependent on the behavior of each asset. Mature markets / Developed markets continue to provide over a long period of time high return with low volatility. Amongst emerging markets except for India and China, all other countries exhibited low returns (sometimes negative returns with high volatility) (Raju \& Ghosh, 2004). Many value-at-risk models for measuring market risk require the estimation of volatility parameter. Portfolio diversifications and hedging strategies also require information on stock behavior as a key input. Peripatetic stock prices and their behavior, which have now become endemic features of securities markets, add to the concern. The growing linkages of national markets in currency, commodity and stock with world markets and the existence of common players, have given stock price behavior a new property - that of its speedy transmissibility across markets. The issues of stock price behavior and risk have become increasingly important in recent times to financial practitioners, market participants, regulators, and researchers. The present study aims to review the existing literature of the theories explaining stock price behavior.

\section{Pre Modern Era in Financial Theory}

As the foundation of modern financial innovations and theories, Bernouli's Definition and Measure of risk, Irving Fisher's Asset return in terms of probability Distribution, Keyne's Liquidity Preference Theory, Marsckak's Preference for investment by Indifference curve in mean variance space, Neuman\&Morgen's Theory of choice under uncertainty play a vital role in pre modern era in financial theories. (Ang, Goetzmann\& Schaefer, 2011; Barakat, Elgazzar\&Hanafy, 2015; Lin, Fang \& Cheng, 2008).

\section{Theories in Modern Financial Economics with Technological Development (computing)}

After the end of World War II, the traditional approach of financial theories got a big turn into a modern era. (Archer and D’ Ambrosio, 1969). In this sense, emphasis was placed on sources of resources. However, the early 1950s brought rapid economic expansion, pushing internal controls for accounts receivable, accounts payable, and inventory into the spotlight (Weston, 1975). The post-war period therefore saw a change of focus in finance studies, which began to feature the dominance of internal routines and the concern with organizational structure that characterize the administrative approach, according to Archer and D'Ambrosio (1969).

In addition to the raising of resources, the management of cyclic assets gained importance during this economic phase that required firms to improve their organizational performance, and financial management was forced to evolve in this aspect. Between the late 1950s and the early 1960s, corporate profitability was reduced, and the appearance of new companies meant that resources became scarce for traditional firms. The study of capital costs with a view to analyzing the feasibility of investments also gained importance, as did trying to deepen understanding of the international economy; it was a time to search for new markets (Weston, 1975). In the beginning of 1950s, two mainstreams formed the foundations of modern finance. The first one is called Corporate Finance, set forth by Modigliani and Miller (1958). The other, which focuses on portfolio and risk and return studies, was introduced by Markowitz (1952), and has followers in authors such as Tobin (1958) and Sharpe (1964), but its importance was not recognized until the 1970s.

\subsection{Modern Portfolio Theory/Mean-Variance Analysis (1952)}

Harry M. Markowitz published in 1952 a path-breaking article (Markowitz, 1952), in which he argued that the traditional application of one-dimensional investment criteria such as the Net Present value (NPV) criterion 
should be replaced by two dimensions: Expected returns and risk defined as the standard deviation of the return distribution. (Balling \& Gnan, 2013) In 1990, Markowitz received the Nobel Prize in economics for having developed a strong analytical basis for that wise recommendation, which can be followed by individuals, firms, mutual funds and institutional investors.

Markowitz (1952) spread the notion that investors should build their portfolios on the basis of expected returns (desirable) and returns variance (undesirable), in order to maximize the former and minimize the latter, by diversifying assets with reduced covariance. Markowitz (1952) rejected the idea that investors should base their portfolios solely on the greatest expected return, because adopting this criterion may lead to two assets with similar returns being allocated to the investment portfolio with no analysis of their contribution to its risk. $\mathrm{He}$ also explained that a portfolio with the maximum expected return is not necessarily that with the least risk, and stresses that a naively diversified portfolio, which does not account for the relationship between assets (stocks) and considers only their amount, does not necessarily mitigate risk (Saito, Savoia, \& Fama, 2013).

To Markowitz (1952), although diversification allows reduction of portfolio risk, it does not eliminate the variance in a portfolio, that is, diversification does not lead to complete extinction of the risk present in an investment portfolio. One may state that Markowitz (1952) implicitly contributed to our understanding of the concepts of systematic (non-diversifiable) and nonsystematic (diversifiable) risk, which were later explicitly explored by Sharpe (1964). The Markowitz model (1952) was therefore important because it allowed propagation of the understanding that diversifying a portfolio by holding assets with a reduced level of correlation (covariance) is important for mitigating portfolio variance in relation to its expected return (risk). In his article, Markowitz (1952) explained that combining all assets and all risks allows the portfolios with the greatest level of return for a given amount of risk to be identified out of a set containing all possible portfolios. This was named the efficient frontier.

In 1989, J.P. Morgan decided to develop a portfolio model, which was able to measure and explain the risks of the firm on a daily basis. In 1992, J.P. Morgan launched the Risk Metrics methodology to the marketplace for free (J.P. Morgan/Reuters, 1996). The staff of the firm made daily updates of spot prices, volatility estimates and correlation estimates accessible through the internet. They explained that they did so because the firm was interested in promoting greater transparency of market risks; they wanted to establish a benchmark for market risk measurement and to use the Risk Metrics methodology to help clients to understand their portfolio risk. In 1993-1994, J.P. Morgan revised their technical document and popularized the concept Value-at-Risk (VaR) as portfolio risk measure to be applied by financial institutions in the capital adequacy calculations to be presented to financial regulators. VaR is a downside measure estimated by means of historical statistics on volatility and correlations among a sample of financial assets and focusing on the probability of suffering losses. For a given portfolio, probability and time horizon, VaR is defined as a threshold value, which can be used to instruct the portfolio manager to keep the probability of suffering losses below a certain level. (Balling \& Gnan, 2013). VaR actually became the standard for the measurement of portfolio risk with official endorsement in the 1993 proposal from the Basel Committee as well as in the Capital Adequacy Directive (93/6/EEC) from the European Commission. Philippe Jorion has contributed to the popularity of VaR as portfolio risk measure (Jorion, 2006).

\subsection{Separation Theorem/Liquidity Preference Theory (1958)}

Tobin (1958) contributed to the expansion of the concepts introduced by Markowitz (1952). Using Keynesian Theory as a starting point, Tobin (1958) argued that investors choose situations that fall between a state of total liquidity and a point of total investment in high-risk assets. In his work, Tobin (1958) noted that investors prefer liquidity, due to two aspects: one concerns individual inelasticity towards the expected interest rate, and the other, uncertainty as to the future of interest rates. In other words, investors are inclined to avoid the risk of losing the 
wealth of their capital as a consequence of unpredictable asset price fluctuations (market risk). Additionally, Tobin (1958) developed the observation that investors make their decisions by combining a risk-free asset with the portfolio located at the Efficient Frontier introduced by Markowitz (1952), leading to the Separation Theorem, which states that the two investment decisions made by individuals are independent and separate. These decisions consist of:

- Determining the most efficient risky asset portfolio;

- Defining the proportion of resources to be allocated to risk-free assets and risky assets. (Saito, Savoia, \& Fama, 2013)

The Separation Theory that bears his name was Tobin's greatest contribution showing that the most efficient portfolio of risk-bearing investments is independent of personal preferences regarding risk - the difference between an investor with higher risk tolerance and one with lower risk tolerance is the proportion of risk-free assets in his or her portfolio (Famá and Galdão, 1996; Elton and Gruber, 1997; Dimson and Mussavian, 1999).

\subsection{Theory of Capital Structure (1958)}

Modigliani and Miller (1958) introduced a new mainstream on the subject, which was previously characterized by two polarized beliefs: one maintained that the distribution of dividends maximized the value of the company to its stockholders, while the other understood that distributing dividends prevented the company from investing in profitable projects, thus impeding value maximization. They devised the concept that the value of a company is independent of its capital structure. In light of the innovative character of this proposal, Chew (1993) considers Modigliani and Miller to be the founders of modern finance.

Although the assumptions that underlie the original proposal of Modigliani and Miller (1958) - such as the absence of taxes - cannot be wholly ratified in real-world situations, they do allow study of the factors capable of affecting the definition of an adequate corporate capital structure (Amaro de Matos, 2001).

Franco Modigliani and Merton H. Miller published in 1958 an article on the irrelevance of a firm's capital structure in an abstract economy without transaction costs and taxation (Modigliani \& Miller, 1958). The message of the authors was that the value of a firm defined as the sum of the market values of its equity and its debt is independent of the size and composition of the debt, if financial markets are perfect and in equilibrium. Under these ideal conditions, the average cost of capital is also independent of the leverage of the firm. The explanation of this surprising theorem is that the shareholders under the given assumptions are able, without any cost, to compose their portfolios in such a way that they realize the return/risk profile, which they prefer. When investors can do these themselves, they have no incentive to pay more for shares in companies, where the managers try to adjust the capital structure according to what they think the shareholders want. (Balling \& Gnan, 2013) The "Irrelevance Theorem" had a strong influence on later contributions to capital structure theory in the 1960s and 1970s, where researchers focused on the importance of taxation, transaction costs, cost of default etc. i.e. all the financial market characteristics that had been assumed away by Modigliani and Miller.Almost all researchers felt obliged to refer to the 1958 article and to explain why a firm's capital structure within their model framework was relevant.

The irrelevance theorem has been criticized by another Nobel Prize winner Joseph E. Stiglitz (Stiglitz, 1969). Modigliani and Miller assumed that there was no default risk and that there were no information asymmetry problems between the investors and the company managers. These two assumptions are according to Stiglitz unrealistic and if they are removed, the capital structure becomes important. It becomes then possible to discuss a company's funding decisions and the interplay between shareholders, creditors and company managers and the implied corporate governance problems in a much more relevant way. (Balling \& Gnan, 2013)

Stewart C. Myers has written an excellent overview article on other capital structure theories (Myers, 2001). He 
explains the "trade-off theory", which says that firms seek debt levels that balance the tax advantages of additional debt against the costs of possible financial distress. The "Pecking order theory" argues that the firm will borrow, rather than issuing new equity, when internal cash flow is not sufficient to fund capital expenditures. Firms prefer internal to external finance in order not to be dependent on creditors or new shareholders. Finally, the "Free cash flow theory" says that the choice of capital structure is related to the conflicts between managers and shareholders. The owners might prefer higher dividend payments if the company has a good liquidity, but the managers prefer to keep the money in the company and invest in internal expansion. Thus, there are close relations between some capital structure theories and agency theory. (Balling \& Gnan, 2013)

\subsection{Capital Asset Pricing Model (1964)}

The Capital Asset Pricing Model (CAPM), devised in the seminal work of Markowitz (1952) and Tobin (1958) and later simplified by Sharpe (1963; 1964), Lintner(1965; 1969), and Mossin (1966), considers returns expected by resource suppliers to be determined by the risk-free rate, plus the expected market risk premium adjusted by the beta coefficient. This simplification of the Markowitz model allowed observation of the fact that total asset risk is composed of systematic and non-systematic (or diversifiable) risk, broadening understanding of the matter. The understanding that systematic risk affects assets was extremely important, because, as explained by Assafand Neto (2003), this is one of the most relevant risks, as it cannot be mitigated through asset diversification.

Sharpe (1964) clarified that, in the presence of a single risk-free interest rate for obtaining resources or investing, there exists a point on the efficient frontier whose corresponding portfolio will be held by all investors, regardless of their personal risk profiles. The CAPM explains that the super-efficient portfolio obtained through the combination of risk-free and risky assets is located at the point of tangency between the Capital Market Line $(\mathrm{CML})$ and the efficient frontier. The CML represents a set of combinations of risk-free and risky assets, which will be considered by all investors (homogeneous expectations), and the point where the CML meets the efficient frontier is known as the Market Portfolio. Sharpe (1964) concluded that this super-efficient portfolio is the market itself; according to him, investors cannot obtain above-market returns in a consistent manner, because the market behaves in a manner conducive to its equilibrium, assuming that all investors are subject to the same risk-free rate.

The CAPM introduced the concept of beta, which measures the covariance between the return of an asset and the market, and represents the contribution of systematic (non-diversifiable) asset risk towards the risk of a diversified portfolio. Therefore, unlike Markowitz (1952), the CAPM explicitly mentions the concept of systematic (non-diversifiable) risk. It is worth mentioning that other models more robust than the CAPM have been developed and have gained relevance, such as Arbitrage Pricing Theory (APT), introduced by Ross in 1976, which offers an alternative to the CAPM in that, in addition to beta, it correlates a " $\mathrm{k}$ " quantity of factors with asset return (Copeland, Weston and Shastri, 2005).

Whereas Black, Jensen and Scholes (1972) and Fama, Eugene and MacBeth (1973) found evidence consistent with CAPM's acceptance, Lakonishok and Shapiro (1986) and Fama and French (1992, 1993, 1996, and 2004) have conducted studies favoring a multifactor approach proposed by Ross (1976). However, their findings and results do not permit a consensus on the multifactor model. Despite of this dilemma, the APT requires more information than the CAPM does, and is thus subject to greater difficulty in obtaining data. This explains the greater applicability of CAPM to professionals who face the challenge of estimating capital costs, despite criticism of its simplicity.

The CAPM has been subject to empirical testing in many studies over the years. Roll (1977) has in strong words even questioned the testability of the model. The outcomes of tests have been mixed, and some authors have 
expressed doubts above the usefulness of the model (Ross, 1978). A serious weakness is that the market participants in the model are assumed to look only one period ahead in time. It has also been criticized that it uses a single risk factor and that this is not quite enough for describing the cross-section of expected returns in the financial market (Miller, 1999). Several authors have tried to overcome such weaknesses by including other risk factors besides the market factor and to cover more than one period (Cox, Ingersoll \& Ross, 1985 and Merton, 1973). Other authors have argued that the CAPM should altogether be rejected. In (Dempsey, 2013) the author argues that after the experiences of the recent financial crisis the CAPM and the theory of efficient markets may need to be replaced with a paradigm of markets as vulnerable to capricious behavior. Some authors have adjusted the assumptions behind the CAPM to include foreign exchange risk in an international environment. In an international capital asset pricing model (ICAPM), investors are assumed to take not only the time value of money and the premium for taking risks on the market portfolio into consideration but also the exposure to foreign exchange risk. The ICAPM assumes that the international capital market is integrated. A test of the performance of the ICAPM has been carried out by (Engel \& Rodrigues, 1989). The authors find that the ICAPM performs much better when variances are not constant over time, nevertheless the model does not perform as well as less restricted models of asset pricing (Balling \& Gnan, 2013).

\subsection{Efficient Market Hypothesis (1970)}

The literature of economics and finance includes three major types of theories for describing stock market performance: classical, behavioral, and the efficient capital market (Cho, 1980). According to classical economic theory, market behavior can be analyzed in terms of the intersection of demand and supply schedules and the stability of this intersection at equilibrium. The mechanism by which this equilibrium is reached is represented by some form of Walrasian process which permits prices to respond to excess demand through a contracting device that allows exchanges to occur only when equilibrium is reached (Negishi, 1962). One consequence of this theory is that all changes in price are the result of shifts in either the demand or the supply schedule, or both. Concurrently, any such movement in price is stated as a series of actual prices over time, thus representing a sequence of equilibrium positions. The second approach to understanding stock price movements is the behavioral theory of the market which tries to explain and predict observable decision making. This theory represents decision makers by a set of decision processes which act on, as well as react to, information already available or which may be procured from the environment. Hence, all behavior is a response by some describable decision processes to an ascertainable body of information (Clarkson, 1964).

The efficient capital market theory has achieved the greatest prominence among the approaches to understanding stock behavior. This theory is characterized by efforts to explain stock price movements through the use of statistical time series models. Fama (1970) defines an efficient capital market as "a market in which prices always fully reflect available information." The efficient markets hypothesis (EMH), popularly known as the Random Walk Theory, is the proposition that current stock prices fully reflect available information about the value of the firm, and there is no way to earn excess profits, (more than the market overall), by using this information. It deals with one of the most fundamental and exciting issues in finance - why prices change in security markets and how those changes take place. It has very important implications for investors as well as for financial managers. The first time the term "efficient market" was in a 1965 paper by E.F. Fama who said that in an efficient market, on the average, competition will cause the full effects of new information on intrinsic values to be reflected "instantaneously" in actual prices.

Many investors try to identify securities that are undervalued, and are expected to increase in value in the future, and particularly those that will increase more than others. Many investors, including investment managers, believe that they can select securities that will outperform the market. They use a variety of forecasting and 
valuation techniques to aid them in their investment decisions. Obviously, any edge that an investor possesses can be translated into substantial profits (Clarke, Jandik and Mandelker, 2001).

The efficient markets hypothesis (EMH) suggests that profiting from predicting price movements is very difficult and unlikely. The main engine behind price changes is the arrival of new information. A market is said to be "efficient" if prices adjust quickly and, on average, without bias, to new information. As a result, the current prices of securities reflect all available information at any given point in time. Consequently, there is no reason to believe that prices are too high or too low. Security prices adjust before an investor has time to trade on and profit from a new a piece of information. The key reason for the existence of an efficient market is the intense competition among investors to profit from any new information. The ability to identify over- and underpriced stocks is very valuable (it would allow investors to buy some stocks for less than their "true" value and sell others for more than they were worth). Consequently, many people spend a significant amount of time and resources in an effort to detect "mispriced" stocks. Naturally, as more and more analysts compete against each other in their effort to take advantage of over- and under-valued securities, the likelihood of being able to find and exploit such mispriced securities becomes smaller and smaller. In equilibrium, only a relatively small number of analysts will be able to profit from the detection of mispriced securities, mostly by chance. For the vast majority of investors, the information analysis payoff would likely not outweigh the transaction costs.

The earliest formal study of stock market efficiency is attributed to Bachelier (1900). His work with commodity prices in France provided convincing evidence that speculation in commodities is a fair game: that the expected future price of a commodity based on past and current prices equals the current price. Unaware of Bachelier's work, the Russian economist Slutsky conducted independent research into the random wolk theory in 1927, with results reported a decade later (Slutsky, 1937). His study confirmed the validity of the fair game theory of stock price changes but also suggested the presence of cyclical patterns. This work went unnoticed by both scholars and practitioners.

A third independent study of a non-rigorous form of random walk model was performed by Working (1934) on commodity prices. He found that "to important extent wheat prices resemble a random differences series, they resemble most closely that which might be derived by cumulating random numbers drawn from a slightly skewed population with standard deviation varying rather systematically through time." Thus, Working's findings again pointed toward speculative market efficiency.

An apparent contradiction of the random walk theory was presented by the Cowles Commission for Research and Economics in 1937 (Cowles \& Jones, 1937). This study confirmed the intuition of most technical market analysts by reporting that stock prices move according to predictable trends. To a large degree the findings of this report were reversed later (Cowles, 1960) when it was discovered that the researchers ' use of price averages over periods of interest invalidated many of the original statistical procedures. Nevertheless, the Commission study seems to have discouraged further investigations of market efficiency for a prolonged period in the United States.

In the early 1950s, Kendall, M and Hill (1953) produced an important empirical study supporting the random walk theory (again, lacking the full rigor now associated with that label). His main work concerned the analysis of economic time series, especially share price indexes and their characteristics. The adaptation from physics of the theory of Brownian motion has been further pursued by Osborne (1959 and 1962), confirming Kendall's conclusions with American data. In similar research Roberts (1959) studied the weekly changes of the Dow-Jones Industrial Averages. He concluded that the history of market levels behaves very much as if these levels had been generated by the accumulation of results generated by chance models. Alexander (1961) reported the first scientific investigation of a variable time model of stock price behavior. He tested a model based on the 
"filter technique," some more research works of Cootner (1962), Granger and Morgenstern (1963) Jenkins and Watts, 1968), Levy (1966) and Jensen (1967) provided the platform work for Fama to express his Efficient Market Hypothesis (1970) that adds a great contribution on the field of finance.

\subsubsection{EMH and Expected Return}

Efficient markets hypothesis (EMH) asserts that in an efficient market price fully reflect available information. This implies that investor can expect to earn a merelyrisk-adjusted return from an investment as prices move instantaneously and randomly to any new information. Efficiency is defined at three different levels, according to the level of information reflected in the prices. Three levels of EMH are expressed as follows: weak form, semi-strong and strong form. Weak-form version of EMH asserts that prices of financial assets reflect all information contained in the past prices. Semi-strong version postulates that prices reflect all the publicly available information. Lastly, strong-form posits that prices of financial assets reflect, in addition to information on past prices and publicly available information, inside information (Fama, 1970, 1991). As EMH states that security prices should fully reflect all available, relevant information, then deviations of actual returns from expected returns should be random they ought, on average, to be zero and uncorrelated with information available to the market. (Tease, 1993)

Stock market acts as an intermediary and channels funds from savers to firms who utilize it to carry out projects. Efficient markets are a necessary prerequisite if it is desired that funds should be allocated to the highest-valued projects. This is possible only if stock prices are efficiently priced i.e. reflect the fundamental value of future discounted cash flows. Also, to the extent that capital markets are efficient, it is easier for the firm to raise capital as the market performs the price discovery process i.e. it determines the price at which market players are willing to exchange claims on firm's future cash flows. (Hameed\&Hammad, 2006) Furthermore, if the general perception prevailing in the market is that prices accurately reflect information, participations cost will be low and the stock market will successfully perform its function of channeling resources to productive projects. From a policy perspective, evidence of capital market efficiency spells out a limited role of the government in the capital markets.

\subsection{Arbitrage Pricing Theory (1976)}

There are two versions of the APT: factor loading model and macro variable model. Factor loading model uses artificial variables created through the factor analysis technique. While macro variable model uses macroeconomic variables based on the economically interpretable effect on stock prices (Erdugan, 2012). Ross (1976) developed the APT and Roll and Ross (1995) provided a more intuitive explanation of the APT and discussed its merits for portfolio management. The APT is an alternative approach to the CAPM that has become the major analytic tool for explaining the phenomena observed in capital markets. The APT is an alternative asset-pricing model to the CAPM differing in its assumptions and explanation of risk factors associated with the risk of an asset. The CAPM specifies returns as a linear function of only systematic risk. The APT specifies returns as a linear function of more than a single factor. It predicts a relationship between the returns of portfolio and the returns of a single asset through a linear combination of variables. The APT approach moved away from the risk versus return logic of the CAPM, and exploited the notion of "pricing by arbitrage" to its fullest possible extent. As Ross (1976) has noted, arbitrage-theoretic reasoning is not unique to his particular theory but is in fact the underlying logic and methodology of virtually all of finance theory. There are many multifactor assets pricing models developed in the literature. According to Sinclair (1984), all of the multifactor asset pricing models developed in the literature can be treated as special theoretical cases of the APT.

The APT has been empirically investigated in the US and elsewhere. Examples are: Roll and Ross (1980), Chen (1983), Chen et.al (1986), Priestly (1996), Clare and Thomas (1994), Cheng (1995 and 1998), Chen and Jordan 
(1993), Merville et al. (2001), Chen et al. (1997), Beenstock and Chan (1986) and Cho et al. (1984). There are a number of empirical studies of APT using Australian data, such as: Sinclair (1984); Groenewold and Fraser (1997), Faff and Chan (1998). Groenewold and Fraser (1997) compared the factor loading model and the macro variable model of the APT and the CAPM. Both versions of the APT were found to clearly outperform the CAPM, but neither version of the APT was clearly superior to the other in terms of both within and out-of-sample explanatory power. The factor loading model uses factor analysis technique based on artificial factors to identify the number of factors and their significance in estimating the responsiveness of individual securities to different systematic risk factors. The macro variable model uses an alternative methodology avoiding artificial factors. The macro variable model is based on economic interactions and it tries to explain the relationship between the stock market and the economy in terms of what economic theory suggests. Roll and Ross (1980), as suggested by Ross (1976) tested the APT using the factor analysis technique with artificial variables. It has become a classic article on testing the APT. They found that there are at least three and probably four significant factors. However, they could not determine which macroeconomic variables were significantly priced. Beenstock and Chan (1986), using the factor analytic technique similar to Chen (1983), found results similar to Dhrymeset al. (1984) in the UK stock market. They described 20 risk factors in the UK stock market. Furthermore, they reported that the number of factors is proportionate to the sample size.

3.7Theories in Value Creation, CSR and Behavioral Finance

In 1973, Fischer Black and Myron S. Scholes published an article (Black and Scholes, 1973), which revolutionized financial theory and laid the foundation of a phenomenal growth in derivatives markets in the following decades. The so-called "Black-Scholes Formula" determines the value of a European call option as a function of the exercise price, the market price of the underlying asset, the time distance to exercise, the risk-free interest rate and the volatility of the underlying asset. The formula is based on the assumption that investors are able continually to adjust their portfolios. Since investors cannot do that in practice, the formula is an approximation. In spite of the simplifying assumptions, the formula has proved to be highly useable in the real world. It is today applied on all markets for derivatives in the world. Information in annual reports from listed companies on the value of stock options awarded to members of the company management is in most cases based on the Black-Scholes Formula. In 1997, Myron S. Scholes and Robert C. Merton were awarded the Nobel Prize in Economics for their research. In cooperation with Black and Scholes, Merton expanded option pricing theory with a view to several practical applications. (Merton, 1973). He used the formula in capital asset pricing, management of pension funds and management of mutual funds. In 1993, Merton was one of the initiators in the establishment of the fund Long-Term Capital Management (LTCM), which, after heavy losses, was reconstructed through a crisis package in 1998. The LTCM failure was in itself a milestone in the sense that it showed that even highly qualified financial researchers could be responsible for financial distress. The failure provided important lessons to learn for financial regulators with responsibility for derivatives markets. A common assumption behind the theoretical models explained above is that persons and institutions are assumed to behave in a rational way. They have a goal or a preference function and they try consistently through their decisions to optimize their income, wealth or utility within the possibilities they are confronted with in the financial market. In the field "behavioral finance", researchers question the rationality assumptions in conventional financial theory and try through a multidisciplinary approach to understand financial behavior in the context of psychology, sociology, anthropology etc. In the 2012 volume of the Journal of Behavioral Finance, the authors write about psychological influences on market fluctuations, risk perceptions of investment products, risk-seeking behavior of troubled firms etc. Some authors belonging to this group have argued that the recent unsatisfactory performance of the financial system documents that there is a need for a revolution in financial 
thinking (Gippel, 2013).

In the 1990s, a lot of the focus of academic discussion shifted away from econometric analyses of time series on prices, dividends and earnings toward developing models of human psychology as it relates to financial markets. The field of behavioral finance developed. (Shiller, 2003). Behavioral finance attempts to explain and increase understanding of the reasoning patterns of investors, including the emotional processes involved and the degree to which they influence the decision-making process. Essentially, behavioral finance attempts to explain the what, why, and how of finance and investing, from a human perspective. For instance, behavioral finance studies financial markets as well as providing explanations to many stock market anomalies (such as the January effect), speculative market bubbles (the recent retail Internet stock crash of 1999), and crashes (crash of 1929 and 1987) (Statman, 2010). There has been considerable debate over the real definition and validity of behavioral finance since the field itself is still developing and refining itself. This evolutionary process continues to occur because many scholars have such a diverse and wide range of academic and professional specialties. Lastly, behavioral finance studies the psychological and sociological factors that influence the financial decision making process of individuals, groups, and entities.

\section{Conclusion}

In this study, some basic theories are mentioned that are relevant to explaining stock price behavior. There has been a remarkable interaction between theory and practice. Academic research has contributed to the understanding of investor behavior and the functioning of financial markets. Academic research has also stimulated financial innovation and led to development of new financial instruments and markets (Balling \& Gnan, 2013). So, the review of the existing literature on stock price behavior can contributed to future research to step ahead to the next directions.

\section{References}

Abid Hameed, Hammad Ashraf. (2006). Stock Market Volatility and Weak-Form Efficiency: Evidence from an Emerging Market. The Pakistan Development Review, 45(Winter), 1029-1040.

Alexander, S.S. (1961), Price Movements in Speculative Markets: Trends or Random Walks, Industrial Management Review, 2 (2), 7-26.

Amaro De Matos, J. (2001). Theoretical Foundations of Corporate Finance.Princeton, NJ: Princeton University Press

Ang, A., Goetzmann, W. N., \& Schaefer, S. M. (2011). Review of the Efficient Market theory and Evidence, 1-64. Archer, S. H. and D’Ambrosio, E.C. (1969).Administração Financeira: Teoria E Aplicação. São Paulo: Atlas.

Assaf Neto, A. (2003). Finanças Corporativas E Valor.São Paulo: Atlas

Bachelier, L., (1901). Mathematical theory of the game.AnnalesScientifiques of the EcoleNormaleSuperieure, 18, $143-210$.

Bachellier L. (1900). Theorie De La Speculation Paris: Gauthier-Villars Reprinted in English (Bones Trans) in Cootner P.H. Edited (1964) the Random Character of Stock Market Prices: M.I.T. Press.

Balling, M., \& Gnan, E. (2013). The Development of Financial Markets and Financial theory: 50 Years of interaction. Suerf 50th Anniversary Volume Chapters, (November), 157-194. Retrieved from http://suerf.org/download/50ymf/50y_ch5.pdf

Barakat, M. R., Elgazzar, S. H., \& Hanafy, K. M. (2015). Impact of Macroeconomic Variables on Stock Markets: Evidence from Emerging Markets. International Journal of Economics and Finance, 8(1), 195. http://doi.org/10.5539/ijef.v8n1p195

Beenstock, M. \& Chan, K. F. (1986). Testing the Arbitrage Pricing theory in the United Kingdom, Oxford Bulletin of Economics and Statistics, 48(2), 121-141. 
Black, F, Scholes M. (1973). The Pricing of Options and Corporate Liabilities. J. Pol. Economy 81,637-654

Black, F., Jensen, M. C. and Scholes, M. (1972). The Capital Asset Pricing Model: Some Empirical Tests. In M.C. Jensen, Studies in the theory of Capital Markets. New York: Praeger.

Chen, N. (1983). Some Empirical Tests of the theory of Arbitrage Pricing.Journal of Finance, 38, 1393-1414.

Chen, N., Roll, R., Ross, S.A. (1986). Economic Forces and the Stock Market, Journal of Business, 59(3), 383-403.

Chen, S.J. \& Jordan, B.D. 1993, Some Empirical Tests in the Arbitrage Pricing theory: Macrovariables Vs. Derived Factors. Journal of Banking and Finance, 7(1),65- 89.

Cheng, A.C.S. 1995, UK Stock Market and Economic Factors: A New Approach. Journal of Business Finance and Accounting, 22,(1),129-142.

Cheng, A.C.S. 1998, International Correlation Structure of Financial Market Movements--the Evidence from the UK and the US, Applied Financial Economics, 8(1), 1-12.

Chew, D. H., Jr. (1993). Introduction: Financial innovation in the 1980S. In the New Corporate Finance.New York: Mcgraw-Hill.

Cho, D.C., Elton, E.J. \& Gruber, M.J. 1984, on the Robustness of the Roll and Ross Arbitage Pricing theory.Journal of Financial and Quantitative Analysis, 19(1),1-12.

Clare, A.D. \& Thomas, S.H. 1994, Macroeconomic Factors, the APT and the UK Stock Market.Journal of Business Finance and Accounting, 21(3), 309-330.

Clarke, J., Jandik, T. \&Mandelker, G. Avalable at: http://www.e-m- h.org/ClJM.pdf

Clarkson, G. P. E. (1964). Empirical Foundations of Economic Analysis.Sloan School of Management, Working Paper, No. 83, M.I.T.

Cootner, Paul H. (1962). An Analysis of Security Recommendations By Brokerage House. Quarterly Review of Economics and Business, 2(2), 19-28.

Cootner, Paul H. (1962). Stock Prices: Random vs. Systematic Changes, industrial Management lii, 24-45.

Copeland, T. E., Weston, J. F., and Shastri, K. (2005).Financial theory and Corporate Policy. USA: Pearson Addison Wesley.

Cowles, A. (1960). A Revision of Previous Conclusions Regarding Stock Market Behavior.Econometrica, 28, 909-915.

Cowles, A., \& Jones, H. E. (1937).Some A Posteriori Probabilities in Stock Market Action.Pdf. Econometrica. https://doi.org/10.2307/1905515

Cox, J.C., Ingersoll, J.E. \& Ross, S.A. (1985), An Intertemporal General Equilibrium Model of Asset Prices, Econometrica, 53(2), 363-84

Dempsey, M. (2013). The Capital Asset Pricing Model (CAPM): the History of A Failed Revolutionary Idea in Finance? Abacus, Vol. 49, Supplement, 2013.Retrieved from http://dx.doi.org/10.1111/j.1467-6281.2012.00379.x.

Dhrymes, P, Friend, I \&Groenewold, B (1984) A Critical Re-Examination of the Empirical Evidence on the Arbitrage Pricing theory.Journal of Finance. 39(20),323-346.

Dimson, E., and Mussavian, M. (1999). Three Centuries of Asset Pricing. Journal of Banking and Finance, 23, 1745-1769.

Dimson, E., and Mussavian, M. (1999). Three Centuries of Asset Pricing. Journal of Banking and Finance, 23, 1745-1769.

Elton, E. J., and Gruber, M. J. (1997).Modern Portfolio theory, 1950 to Date.Journal of Banking and Finance, 21, 


\section{3-1759}

Engel, C. \& Rodrigues, A.P., 1989, Tests of International CapmWith Time-Varying Covariances, Journal of Applied Econometrics, 4, 119-38.

Erdugan, R. (2012). The Effect of Economic Factors on the Performance of the Australian Stock Market.

Faff, R. \& Chan, H. (1998). A Multifactor Model of Gold industry Stock Returns: Evidence from the Australian Equity Market, Applied Financial Economics, 8(1),21-28.

Fama, E. (1970). Efficient Capital Markets: A Review of theory and Empirical Work. The Journal of Finance, 25,(2),283-417.

Fama, E. F. (1991). Efficient Capital Markets: Ii. The Journal of Finance, 46(5), 1575-1617.

Fama, E. F., \& French, K. (1992).The Cross-Section of Expected Stock Returns. The Journal of Finance, 47(2), 427-465.

Fama, E. F., \& French, K. (1993).Common Risk Factors in the Returns on Stocks and Bonds. Journal of Financial Economics, 33, 3-56.

Fama, E. F., \& French, K. (1996).Multifactor Explanation of Asset Pricing Anomalies. The Journal of Finance, 51, 55-84.

Fama, E. F., \& French, K. (2004). The Capital Asset Pricing Model: theory and Evidence. Journal of Economic Perspectives, 18(3), 25-46.

Fama, E. F., (1970), Stock Performance, real activity, inflation and money, American Economic Review, 71, $545-65$

Fama, Eugene F. and James D. Macbeth, 1973, Risk, Return, and Equilibrium: Empirical Tests, Journal of Political Economy 71, 607-636.

Famá, R., and Galdão, A. (1996). A FunçãoFinanceira: Uma AnáliseEsquemática De SuaEvolução. In Anais Do ISemead: 2, 100-105. São Paulo: Fea/Usp

Gippel, J.K., (2013). A Revolution in Finance?Australian Journal of Management, 38(1), 125-46.

Granger, C. W. J. and Morgenstern, O. (1963), Spectral Analysis of New York Stock Market Prices, Kyklos, 16 (1), 1-27.

Groenewold, N. \& Fraser, P. (1997). Share Prices and Macroeconomic Factors, Journal of Business Finance and Accounting, 24, (9/10), 1367-1383.

J. P. Morgan/Reuters. (1996). Risk metrics - Technical Document, 4.Ed, New York and London.

Jenkins, G. M. and Watts, D. G. (1968) Spectral Analysis and Its Applications.Holden Day, San Francisco

Jensen, M. C. (1967). Random Walk: Reality or Myth - Comment. Financial Analysts Journal, 1967, 23(6), $77-85$.

Jorion, P. (2006). Value at Risk: the New Benchmark For Managing Financial Risk, 3.Ed, Mcgraw-Hill, New York.

Kendall, M. G., \& Hill, A. B. (1953). The Analysis of Economic Time-Series-Part I: Prices. Journal of the Royal Statistical Society, Series A (General). https://doi.org/10.2307/2980947

Lakonishok, J., and Shapiro, A. C. (1986). Systematic Risk, total Risk and Size As Determinants of Stock Market Returns. Journal of Banking and Finance, 10(1), 115-132.

Levy, A. R. (1966).An Evaluation of Selected Applications of Stock Market Timing Techniques, Trading Tactics and Trend Analysis.The American University, Washington, D.C., 1966.

Lin, C., Fang, C.-R., \& Cheng, H. (2008). Relationships between Oil Price Shocks and Stock Market: An Empirical Analysis from the Greater China. Energy Policy, 36(9), 3544-3553.

Lintner, John. (1965). Security Prices, Risk, and Maximal Gains from Diversification. Journal of Finance, 20, 
587-616.

Lintner, John. (1969). The Aggregation of investors Diverse Judgments and Preferences in Purely Competitive Security Markets. Journal of Financial and Quantitative Analysis. 4, 347-400.

Markowitz, H. (1952). Portfolio Selection, Journal of Finance, 7(1),77.

Merton, R.C. (1973). An intertemporal Capital Asset Pricing Model, Econometrica, 41,(5), 867-87.

Merville, L.J., Hayes-Yelken, S. \&Xu, Y. (2001).Identifying the Factor Structure of Equity Returns, Journal of Portfolio Management, 27(4), 51-61.

Merville, L.J., Hayes-Yelken, S. \&Xu, Y. (2001).Identifying the Factor Structure of Equity Returns, Journal of Portfolio Management, 27(4), 51-61.

Miller, M. H. \& Modigliani, F. (1961). Dividend Policy, Growth and the Valuation of Shares, The Journal of Business, 34(4),411-33.

Miller, M. H. (1999). The History of Finance.The Journal of Portfolio Management, 95-101. https://doi.org/10.3905/jpm.1999.319752

Modigliani, F. \& Miller, M.H. (1958). The Cost of Capital, Corporation Finance and the theory of investment, American Economic Review, 48(3), 261-297.

Mossin, J. (1966). Equilibrium in a Capital Asset Market, Econometrica, 34(4), 768-783.

Myers, S.C., 2001, Capital Structure, Journal of Economic Perspectives, 15, (2), 81-102.

Negishi, T. (1962). The Stability of Competitive Economy: A Survey Article. Econometrica, J30, 324- 71.

Osborne, M. F. M. 1959. Brownian Motion in the Stock Market. Operations Research, 7, 145-173.

Osborne, M. F. M. 1962, Periodic Structure in the Browian Motion of Stock Prices. Operations Research, 10, 345-79.

Priestley, R. (1996). the Arbitrage Pricing theory, Macroeconomic and Financial Factors, and Expectations Generating Processes, Journal of Banking and Finance, 20(5),869- 690.

Raju, M. T., \&Ghosh, A. (2004).Stock Market Volatility - An International Comparison.Securities and Exchange Board of India, Working Paper Series No. 8.

Roberts, H. V. (1959). Stock Market Patterns and Financial Analysis Methodological Suggestions.Journal of Finance, 14(1), 1-10.

Roll, R. \& Ross, S.A. 1980, An Empirical investigation of the Arbitrage Pricing theory, Journal of Finance, Vol. 35, No. 5, Pp. 1073-1103.

Roll, R. \& Ross, S.A. 1995, the Arbitrage Pricing theory Approach to Strategic Portfolio Planning, Financial Analysts Journal, 51,(1),122-131.

Roll, R. (1977), Oil Prices, Stock Market, Economic Activity and Employment in Greece, Energy Economics, 23, 511-532.

Ross, S.A. 1976, the Arbitrage theory of Capital Asset Pricing, Journal of Economic theory, 13, 341-61.

Ross, Stephen A. 1978A. A Simple Approach to the Valuation of Risky Streams.Journal of Business 51(3),453-75.

Saito, A. T., Savoia, J. R. F., \&Fama, R. (2013).Financial theory evolution.International Journal of Education and Research, 1(4), 1-18.

Sharpe, W. F. 1964, Capital Assets Prices: A theory of Market Equilibrium Under Conditions of Risk, Journal of Finance, 19(3), 425-442.

Sharpe, William F. 1963. A Simplified Model for Portfolio Analysis. Management Science, 19, 277-93.

Shiller, R. J. (2003).From Efficient Markets Theory to Behavioral Finance.Journal of Economic Perspectives, 17(1), 83-104. http://doi.org/10.1257/089533003321164967 
Sinclair, N.A. (1984). Aspects of the Factor Structure Implicit in the Australian industrial Equity Market: February 1958 to August 1977, Australian Journal of Management, 9(1), 23-36.

Slutsky, E. (1937). The Summation of Random Causes as Source of Cyclic Process.Econometrica, 5(2), 105-46.

Statman, M. (2010). What is behavioral finance? Research Foundation Publications, 2(2), 1-12.

Stiglitz, J.E. (1969). A Re-Examination of the Modigliani-Miller theorem, American Economic Review, 59(5), 784-93.

Tease, W. (1993). The Stock Market and investment.OECD Economic Studies, 20 (Spring), 41-63.

Tobin, J. (1958), Liquidity Preference as Behaviour towards Risk, Review of Economic Studies, 25, 65-86.

Weston, J. F. (1975). Finanças De Empresas. São Paulo: Atlas.

Working, H. (1934) A Random-Difference Series for Use in the Analysis of Time Series.Journal of the American Statistical Association 29, 11-24.

\section{Copyrights}

Copyright for this article is retained by the author(s), with first publication rights granted to the journal.

This is an open-access article distributed under the terms and conditions of the Creative Commons Attribution license (http://creativecommons.org/licenses/by/4.0/). 